\title{
The Effect of Teacher Competencies on Student Achievement in Vocational High School
}

\author{
Annas Nur Istiqomah ${ }^{1}$, Suyatno $^{1, *} \&$ Ika Maryani $^{2}$ \\ ${ }^{1}$ Dept. of Educational Management, Ahmad Dahlan University, Pramuka St. 42, Sidikan, \\ Yogyakarta, Indonesia \\ ${ }^{2}$ Dept. of Primary Teacher Education, Ahmad Dahlan University, Ki Ageng Pemanahan St. 19, \\ Sorosutan, Yogyakarta, Indonesia \\ *Corresponding author: Dept. of Educational Management, Ahmad Dahlan University, \\ Pramuka St. 42, Sidikan, Yogyakarta, Indonesia. E-mail: \\ annasnuristiqomahsmkbali@gmail.com
}

Received: October 16, 2019 Accepted: November 29, 2019 Published: December 9, 2019

doi:10.5296/ije.v11i4.15625 URL: https://doi.org/10.5296/ije.v11i4.15625

\begin{abstract}
This research aims to measure the effect of teacher competencies on student learning outcomes. This was a quantitative research by conducting hypothesis testing. The research sample consisted of 60 teachers and 60 students at Muhammadiyah Bambanglipuro Vocational High School, Bantul, Yogyakarta, Indonesia. The data was collected through a questionnaire method. The collected data were analyzed using simple regression with SPSS. Based on calculations with the SPSS Statistics application, it showed the determination result of the independent variable that the determination coefficient showed the direct effect of the teacher competencies variable on learning outcomes stated in percentages. In this case, the calculated result is 0,084 . It means that the teacher competencies variable directly affects the student learning outcome variable by $8,4 \%$, while the $(100 \%-8,4 \%) 91,6 \%$ is influenced by other factors beyond the teacher competencies variable. The findings of this research recommend the importance of teacher competencies development programs, both by the government and schools, because increasing teacher competencies will increase the student learning achievement.
\end{abstract}

Keywords: teacher competencies, student achievement, and vocational high school 


\section{Introduction}

Learning aims to support student achievement. All components in the school such as teachers, school management, and infrastructure must be oriented towards the student learning achievement. When all education components in the school support the learning process, the learning achievement will naturally increase. Student achievement is influenced by internal and external factors.

An educational institution quality can be seen from the quality of its students. This quality can be in the form of individual behaviour and in the academic and non-academic achievement. Novauli (2012) explained that the learning achievement measurement is associated with value, which is an embodiment of the results of student's learning efforts. Whereas Inayah et al. (2013) suggested that learning achievement is a reflection of the results of a learning effort. The better the student's learning effort, the better the learning achievement he/she gets. There are internal and external factors that affect student achievement in learning. Students' internal factors are physiological and psychological conditions, while external factors can be in the form of environment and instrumental factors (Djamarah, 2011).

One of the external factors in improving learning achievement is the teacher. Hadis \& Nurhayati (2012) stated that teachers can support students in obtaining good learning achievement. This is in line with Utomo et al. (2012), who said that teacher is an important component in the education process. The teacher has an important role to change the students behavior and thinking in order to achieve the educational goals. Therefore, teachers must have readiness and competencies in organizing learning (Inayah et al., 2013).

The teacher competencies is an important factor in obtaining student learning achievement. In other words, student learning achievement is a reflection of the teachers' success in teaching. Ideally, with high competencies, student achievement must also better. Teachers who have good abilities can improve student achievement (Akiri, 2013; Baedowi, 2015; Cunningham, 2012; Muzenda, 2013).

Muhammadiyah 1 Bambanglipuro Vocational High School is a vocational education institution. When viewed from the average score of each class that has been achieved, it can be said that in general $75 \%$ of student achievement was relatively unsatisfactory. It was because there were still many students who got grades below the average. In understanding the effect of teacher potential and student achievement, teachers in schools can identify important factors that influence student achievement. Therefore, it can be a valuable information for schools to make management improvements. Improving student achievement is an important factor as a benchmark for the success of educational institutions in carrying out its activities. Actions to identify important factors that affect student achievement are the right action to evaluate the achievement of these successes.

\subsection{Research Objective}

This research aims to measure the effect of teacher competencies on student achievement in Muhammadiyah Bambanglipuro Vocational High School, Bantul, Yogyakarta. 


\section{Literature Review}

\subsection{Teacher Competencies}

Parker-Stanford (2014) defined competency as a professional ability to apply knowledge, skills, and experience in carrying out activities in certain jobs to produce the required results. Similarly, Trinder (2008) defined competency as a professional ability to apply knowledge, skills, and experience in carrying out activities in certain jobs to produce the required results.

Teacher competencies are the accumulation of the teacher's ability to carry out the learning process in the classroom (Abe, 2014; Carreker \& Boulware, 2015). Taghipourzahir (2010) divided teacher competencies into two categories, which are vocational and personality. Personality competencies are mental and physical health, adherence to values, and good mental abilities. Whereas, vocational competencies are general knowledge, vocational knowledge, and communication skills.

Teacher competencies refer to the performance and rational actions in order to meet certain specifications when carrying out educational tasks (Mulyasa, 2007). Teacher competencies contains multi-dimensional constructive, both in the form of pedagogical and professional competencies (Baumert \& Kunter, 2006). Hospesová \& Tichá (2000) mentioned that teacher competencies are pedagogical competency, subject-didactic competency, pedagogical-organizational competency, and the ability to conduct self-reflection. Redding (2014) and Carreker \& Boulware (2015) stated that there are four teacher competencies, which are cognitive competency, metacognitive competency, motivational competency, and emotional/social competency.

Competencies are very important for teachers in carrying out successful learning, thus it needs to be developed. Passos (2009) stated that competencies can be developed through education, experience through work, and training in the workplace. Teaching experience can also improve the teachers' ability to cope with unusual things. While education gives teachers a strong understanding about the subject matter. Work-related education and experience also enhances the teachers' understanding on the principles and concepts underlying mathematical learning that efficient and effective.

Educators must demonstrate the following three competencies: 1) managing class effectively; 2) implementing effective teaching practices, and 3) mastering technological skills that can help learning (Nessipbayeva, 2012). Competent teachers must meet the professional requirements so as to uphold professional standards and norms (Trinder, 2008; Zuzovsky, 2003). In addition, qualified teachers are also required to have teaching abilities recognition from a trusted institution so that the teacher has a license (Musau \& Abere, 2015).

Not quite similar to the theories explained by experts, in Indonesia, teacher competencies are divided into four types, which are pedagogic, professional, personality, and social. Law Number 14 of 2005 concerning Teachers and Lecturers, Article 10 paragraph (1) stated that "teacher competencies include pedagogical competency, personal competency, social competency, and professional competency obtained through professional education". Pedagogical competency is the abilities to understand the students, the learning design and 
implementation, learning outcomes evaluation, and the students development in actualizing their various potentials. Professional Competency is the extensive and in-depth mastery of learning material, which includes the mastery of school subjects curriculum material and the scientific substance that houses the material, as well as mastery of the knowledge structure and methodology. Social Competeny is the teachers' abilities to communicate and socialize effectively with students, education personnel, students' parents/guardians, and surrounding communities. Personality competeny is a personal ability that reflects a personality that is steady, stable, mature, wise and authoritative, a good model for the students, and have good character.

\subsection{The Effect of Teacher Competencies on Student Achievement}

Student achievement is the students accomplishment level in terms of knowledge, skills, and learning experiences that formulated by learning objectives in the school curriculum (Levpuscek \& Zupancic, 2008; Nemeth \& Long, 2012). There are many researches that connecting teacher competencies and student learning achievement in school. Among the many factors that influence student achievement, teacher competencies is the factor most frequently studied (Darling-Hammond, 2000; Heck, 2007; Jennings \& Greenberg, 2009; Joy et al., 2013; Kunter et al., 2013; Lee et al., 2013; Muzenda, 2013; Ottmar et al., 2015; Wayne \& Youngs, 2003). This is because competent teachers are able to create an effective and fun learning environment as well as managing classrooms so that student learning is more optimal (Hamalik, 2008; Prasertcharoensuk et al., 2015).

\subsection{Hypothesis}

Based on the theoretical studies that have been carried out, this research formulates the following hypotheses:

There are positive effects of teacher competencies on student achievement in Muhammadiyah 1 Bambanglipuro Vocational High School.

\section{Methodology}

This study used the quantitative research approach to test the hypotheses. Based on the saturated sampling techniques, 60 teachers and 60 students were selected as data sources for this research. While the statistical analysis was by multiple linear regression and processed by SPSS 13 version for windows. The processed product was analyzed descriptively. After assessing the instruments feasibility in this research, it was worth noting for respondents were 60 teachers and 100 students. Research respondents demographic can be seen in Tables 1 and 2 . 
Table 1. Teachers Respondent Demographic

\begin{tabular}{lllllllllllc}
\hline \multirow{2}{*}{ No } & \multirow{2}{*}{ Identtity } & \multicolumn{3}{l}{ Gender } & \multicolumn{2}{c}{ age (in years) } & \multicolumn{3}{c}{ Education } & \multicolumn{2}{c}{ Teaching period (in Years) } \\
\cline { 3 - 11 } & & Male & Female & $20-30$ & $31-40$ & $40-60$ & S1 & S2 & $1-10$ & $11-20$ & $21-30$ \\
\hline 1 & Total & 35 & 25 & 21 & 20 & 19 & 58 & 2 & 28 & 25 & 7 \\
2 & Percentage & 58.33 & 41.67 & 35.00 & 33.33 & 31.67 & 96.67 & 3.33 & 46.67 & 41.67 & 11.67 \\
\hline
\end{tabular}

Table 2. Students Respondent Demographic

\begin{tabular}{ccccccc}
\hline \multirow{2}{*}{ No } & \multirow{2}{*}{ Identity } & \multicolumn{2}{c}{ Gender } & \multicolumn{3}{c}{ Age in years } \\
\cline { 3 - 7 } & & Male & Female & 16 & 17 & 18 \\
\hline 1 & Total & 58 & 2 & 12 & 28 & 20 \\
2 & Percentage & 96.7 & 3.33 & 20.00 & 46.67 & 33.33 \\
\hline
\end{tabular}

Data collection technique was by questionnaire methods and data collection instrument by questionnaire. There were two questionnaires used namely the teacher competency questionnaire and student achievement questionnaire. The teacher competency questionnaire was filled by 60 teachers which was used to measure teacher competencies. The student achievement questionnaire was filled by 60 students which was used to measure student achievement. The teacher competency questionnaire consisted of 30 statements describing four teacher competencies; pedagogic, professional, personality, and social. Student achievement questionnaire consisted of 30 statements describing student achievement in cognitive, affective, and psychomotor aspects. Each statement was made based on each sub-variable indicators supported by the theory used.

The steps in testing the hypotheses in this research were as follows: descriptive statistics test, classical assumption with stages test, normality tests; multicollinearity test, heteroscedasticity test, and hypothesis test. The equation for testing the hypotheses was: $Y=\alpha+\beta . X(Y=$ student learning outcomes; $\mathrm{X}=$ teacher competencies). Regression analysis was performed to find out the reinforcement between the independent variable and the dependent variable. The statistics test carried out were the estimation of the accuracy/coefficient of determination (R2) model, the simultaneous significance test ( $\mathrm{F}$ test), and the test of the significance of individual parameters (t-test). Testing Requirements of the classical assumption test ensures that there was accuracy in estimation, consistency, and reduction of bias in parameters. Therefore there were no deviation from the assumptions of normality, multicollinearity, and heteroscedasticity. The SPSS program was used to test the existence of the classical assumption deviation. Validity and Reliability of Test Results, the validity and reliability of research instruments was determined in this research.

The validity test was performed by the correlation test of Microsoft Excel and SPSS 21 calculations with the following conditions: When the value of Rhitung $\geq$ Rtable then the research instrument is said to be valid and when the value of Rhitung $\geq$ Rtable then the research instrument is said to be invalid. At a predetermined significance level of $5 \%$, it was obtained Rtable value of 0.361 . The information about instrument validity and reliability is shown in 
Table 2.

\section{Findings}

The steps taken to test the hypotheses in this research were descriptive statistic test, classical assumption test with the following stages: normality test; multicollinearity test, heteroscedasticity test, and hypotheses test. The equation for testing the hypotheses is: $\mathrm{Y}=\alpha+$ $\beta$. $\mathrm{X}(\mathrm{Y}=$ student learning outcomes; $\mathrm{X}=$ teacher competencies $)$. Regression analysis was performed to find out the reinforcement between the independent variable and the dependent variable. The statistics test carried out were the estimation of the accuracy/coefficient of determination (R2) model, the simultaneous significance test (F test), and the test of the significance of individual parameters.

\subsection{Descriptive Statisttics Test}

Table 3. Descriptive Statisttics

\begin{tabular}{cccccccccc}
\hline & $\mathrm{N}$ & Range & Minimum & Maximum & Sum & \multicolumn{2}{c}{ Mean } & \multicolumn{2}{c}{$\begin{array}{c}\text { Std. } \\
\text { Deviation } \\
\text { Variance }\end{array}$} \\
& Statistic & Statistic & Statistic & Statistic & Statistic & Statistic & Std.Error & Statistic & Statistic \\
\hline $\begin{array}{c}\text { Teacher } \\
\text { Competence } \\
\begin{array}{c}\text { Student } \\
\text { Achievement } \\
\text { Valid N } \\
\text { (listwise) }\end{array}\end{array}$ & 60 & 36 & 58 & 94 & 4641 & 77.35 & .834 & 6.457 & 41.689 \\
\hline
\end{tabular}

\subsection{Classical Assumptions Test}

- Normality Test

The data normality was tested by the Kolmogrov Smirnov. It was because the sample used in the study was more than 50 respondents, thus the normality was by the Kolmogrov Smirnov. This normality test was to find out whether the questionnaire results were normally distributed or not. 
Table 4. Normality Test

\begin{tabular}{ccc}
\hline \multicolumn{2}{c}{ One-Sample Kolmogorov-Smirnov Test } \\
$\mathrm{N}$ & Unstandardized Residual \\
\hline Normal Parameters ${ }^{\mathrm{a}, \mathrm{b}}$ & Mean & 60 \\
& Std. Deviation & .0000000 \\
Most Extreme Differences & Absolute & 6.18071491 \\
& Positive & .098 \\
& Negative & .098 \\
Kolmogorov-Smirnov Z & & -.077 \\
Asymp. Sig. (2-tailed) & & .763 \\
\hline
\end{tabular}

a. Test distribution is normal.

b. Calculated from data.

Based on the table (in the Kolmogrov Smirnov column), the significant value is 0.60 . When compared with the level of significance $\alpha=0.05$, the result is $0.60>0.05$ so $\mathrm{H}_{0}$ is accepted (not rejected). Therefore, it can be concluded that:

a) The teacher competencies variable value is normally distributed or taken from the normal population.

b) The student learning outcome variable value is normally distributed or taken from the normal population

- Multicollinearity Test

Looking at the VIF value and then:

a) When the VIF value is more than 10 , then the test data has multicollinearity

b) Whereas when the VIF value is below 10, then the tested data does not have a collinearity.

Hypothesis

VIF result $>10$ then there is multicollinearity

VIF result $<10$ then there is no multicollinearity

Before tested with the SPSS 21 software, it was obtained the following input:

Table 5. Multicollinearity Test

\begin{tabular}{|c|c|c|c|c|c|c|c|c|}
\hline & \multicolumn{8}{|c|}{ Coefficients $^{\text {a }}$} \\
\hline \multirow{3}{*}{ Model } & & \multirow{2}{*}{\multicolumn{2}{|c|}{$\begin{array}{c}\text { Unstandardized } \\
\text { Coefficients }\end{array}$}} & \multirow{3}{*}{$\begin{array}{c}\text { Unstandardized } \\
\text { Coefficients } \\
\text { Beta }\end{array}$} & \multirow{3}{*}{$\mathrm{t}$} & \multirow{3}{*}{ Sig. } & \multirow{2}{*}{\multicolumn{2}{|c|}{$\begin{array}{c}\text { Collinearity } \\
\text { Statistics }\end{array}$}} \\
\hline & & & & & & & & \\
\hline & & B & Std. Error & & & & Tolerance & VIF \\
\hline \multirow[b]{2}{*}{1} & (Constant) & 138.373 & 13.295 & & 10.408 & .000 & & \\
\hline & $\begin{array}{c}\text { Teacher } \\
\text { Competence }\end{array}$ & -.394 & .171 & -.289 & -2.301 & .025 & 1.000 & 1.000 \\
\hline
\end{tabular}


a. Dependent Variable: Student Achievement

Based on the table in the Tolerance and VIF columns, it can be seen that the teacher competencies variable $1,000<10$ does not occur multicollinearity.

- Heteroscedasticity Test

1) Sparman Test Method

a) Hypothesis

$H_{0}>0.05$ then it can be said that there is no heteroscedasticity problem in the the data. $H_{1}<$ 0.05 it can be said that there is heteroscedasticity problem in the the data. Significant level a $=0.05$

b) Calculation

Before being tested with the SPSS 21 software, the data was transformed in the form of absolute residuals and then analyzed using the Sparman test method, and the following inputs were obtained:

Table 6. Heteroscedasticity Test

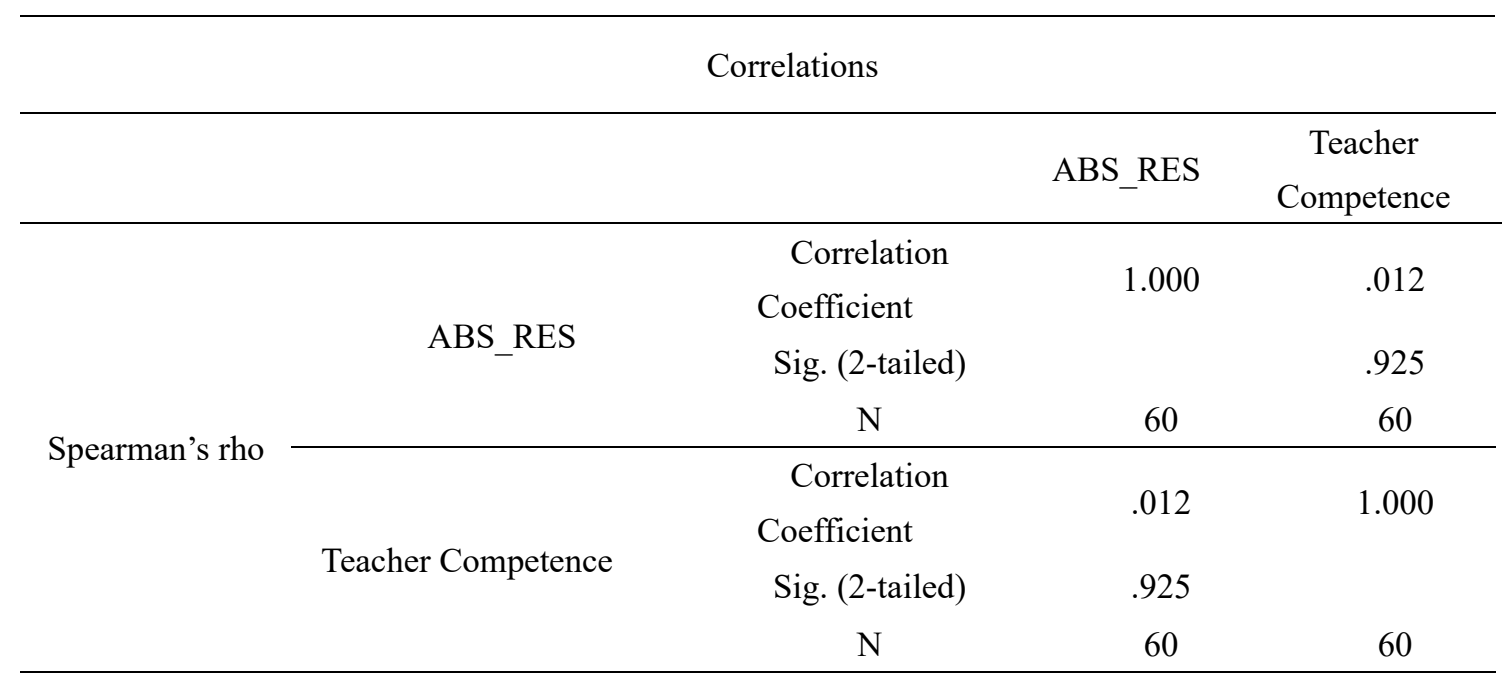

Based on the table in the sig column, it ca be seen that the teacher competencies variable $0,925>0.05$ then Ho is accepted (not rejected). Based on the above analysis it can be concluded that the value of the teacher competencies variable does not occur heteroscedasticity problem.

\section{- Autocorrelation Test}

Autocorrelation is one of the classical assumption test used to find out whether in a linear regression model there is a correlation between error interfering with period $t$ with error in period t-1. It means the current condition is influenced by previous conditions, in other words, auto correlation often occurs in time series data. Good data is data the one that does not have auto correlation in it. 
a) Hypothesis

d values range from 0 to 4 , with the following conditions:

$4-\mathrm{dL}<\mathrm{d}<4$ then has a negative autocorrelation

$4-\mathrm{dU}<\mathrm{d}<4-\mathrm{dL}$ then there is no conclusion

$\mathrm{dU}<\mathrm{d}<4-\mathrm{dU}$ then has no autocorrelation

$\mathrm{dL}<\mathrm{d}<\mathrm{dU}$ then there is no conclusion

$0<\mathrm{d}<\mathrm{dL}$ has positive autocorrelation

b) Calculation

Before tested with the SPSS 21 software, it was obtained input as follows:

Table 7. Autocorrelation Test

\begin{tabular}{cccccc}
\hline \multicolumn{5}{c}{ Model Summary $^{\mathrm{b}}$} \\
\hline Model & $\mathrm{R}$ & R Square & Adjusted R Square & Std. Error of the Estimate & Durbin-Watson \\
\hline 1 & $.289^{\mathrm{a}}$ & .084 & .068 & 8.495 & 1.684 \\
\hline
\end{tabular}
a. Predictors: (constant), Teacher Competence
b. Dependent Variable: Student Achievement

The results of the above calculation in the Durbin-Watson column section, it found that the autocorrelation value is 1.684 . These results are compared with the stated hypothesis, the values of $\mathrm{dU}$ and $\mathrm{dL}$ are taken based on the Durbin Watson table. The value of $\mathrm{dU}=1.6162$ and $\mathrm{dL}=1.5485$ then the test result is $\mathrm{dU}<\mathrm{d}<4-\mathrm{dU}$ which is $1.6162<1.684<2.3838$ then it does not have autocorrelation. Therefore, it can be concluded that the teacher competencies as an independent variable does not have an autocorrelation towards the regression test that later conducted.

\section{- Linearity Test}

When the value of deviation from linearity sig. $>0.05$, then there is a significant linear correlation between teacher competencies and student learning outcomes. The value of deviation from linearity sig. $<0.05$ then there is no significant linear correlation between teacher competencies with student learning outcomes Significant level a $=0.05$.

Before tested with the SPSS 21 software, it was obtained the following input: 
Table 8. Linearity Test

\begin{tabular}{|c|c|c|c|c|c|c|c|}
\hline \multicolumn{8}{|c|}{ ANOVA Table } \\
\hline & & & $\begin{array}{l}\text { Sum of } \\
\text { Squares }\end{array}$ & $\mathrm{df}$ & $\begin{array}{l}\text { Mean } \\
\text { Square }\end{array}$ & $\mathrm{F}$ & Sig. \\
\hline \multirow{6}{*}{$\begin{array}{c}\text { Student } \\
\text { Achievement* } \\
\text { Teacher } \\
\text { Competence }\end{array}$} & \multirow{3}{*}{$\begin{array}{c}\text { Between } \\
\text { Groups }\end{array}$} & (combined) & 2053.413 & 21 & 97.782 & 1.478 & .145 \\
\hline & & Linearity & 382.179 & 1 & 382.179 & 5.775 & .021 \\
\hline & & Deviation from & 1671.234 & 20 & 83.562 & 1.263 & .261 \\
\hline & Within & & & & & & \\
\hline & Groups & & 2514.770 & 38 & 66.178 & & \\
\hline & Tobal & & 4568.183 & 59 & & & \\
\hline
\end{tabular}

Based on the table above, it can be seen that the value of deviation from linearity sig. is 0.261 . When compared with the level of significance $\alpha=0.05$, the result is $0.261>0.05$ thus there is a significant linear correlation between teacher competencies and student learning outcomes.

- Regression Line Equation

Table 9. Regression Line Equation

\begin{tabular}{|c|c|c|c|c|c|c|}
\hline \multicolumn{7}{|c|}{ Coefficients ${ }^{\text {a }}$} \\
\hline \multirow{3}{*}{ Model } & & \multirow{2}{*}{\multicolumn{2}{|c|}{$\begin{array}{c}\text { Unstandardized } \\
\text { Coefficients }\end{array}$}} & \multirow{3}{*}{$\begin{array}{c}\text { Unstandardized } \\
\text { Coefficients }\end{array}$} & \multirow{3}{*}{$\mathrm{t}$} & \multirow{3}{*}{ Sig. } \\
\hline & & & & & & \\
\hline & & $\mathrm{B}$ & Std. Error & & & \\
\hline \multirow[b]{2}{*}{1} & (Constant) & 138.373 & 13.295 & & 10.408 & .000 \\
\hline & $\begin{array}{c}\text { Teacher } \\
\text { Competence }\end{array}$ & -.394 & .171 & -.289 & -2.301 & .025 \\
\hline
\end{tabular}

a. Dependent Variable: Student Achievement

Based on the regression test results above, the regression equation is obtained as follows:

$$
\mathrm{Y}=138.373-0,394
$$

Information: $\mathrm{Y}=$ learning outcomes, $\mathrm{a}=$ constant, $\mathrm{X}_{\mathrm{I}}=$ teacher competencies

The coefficients of the simple linear regression equation above can be interpreted as follows:

a) Constant (a) of 138,373 has the meaning that if the independent variable consisting of teacher competencies is considered constant, then the learning outcomes is 138,373

b) The teacher competencies regression coefficient is $-0,394$, it means that each increase in the teacher competencies ratio of 1 unit will reduce learning outcomes by 0,394 units, or if the teacher competencies decreases by 1 unit, then an increase in 
learning outcomes is $-0,394$

- Hypothesis testing

To determine the presence or absence of the influence of teacher competencies on student learning outcomes, a simple regression analysis was performed. In this case it would be analyzed from the partial results to determine the research hypothesis. The following are the results of the test with SPSS 21

$H_{0}>0.05$ then the teacher competencies do not affect student learning outcomes

$H_{1}<0.05$ teacher competencies affect learning outcomes

Significant level $\mathrm{a}=0.05$

Table 10. Hypothesis Coefficients

\begin{tabular}{|c|c|c|c|c|c|c|}
\hline \multicolumn{7}{|c|}{ Coefficients $^{\text {a }}$} \\
\hline \multirow{3}{*}{ Model } & & \multirow{2}{*}{\multicolumn{2}{|c|}{$\begin{array}{c}\text { Unstandardized } \\
\text { Coefficients }\end{array}$}} & \multirow{3}{*}{$\begin{array}{c}\text { Unstandardized } \\
\text { Coefficients } \\
\text { Beta }\end{array}$} & \multirow{3}{*}{$\mathrm{t}$} & \multirow{3}{*}{ Sig. } \\
\hline & & & & & & \\
\hline & & B & Std. Error & & & \\
\hline \multirow[b]{2}{*}{1} & (Constant) & 138.373 & 13.295 & & 10.408 & .000 \\
\hline & $\begin{array}{c}\text { Teacher } \\
\text { Competence }\end{array}$ & -.394 & .171 & -.289 & -2.301 & .025 \\
\hline
\end{tabular}

Based on the results of the hypothesis test, it was found that level of the significance 0,02 was $0,02<0,05$, then $\mathrm{H}_{1}$ was accepted (not rejected). Thus it can be concluded that teacher competencies have significant effect on learning outcomes.

Based on calculations with the SPSS Statistics application, the results of the independent variables determination showed that the determination coefficient shows the teacher competencies variable has direct effect on learning outcomes, which stated in a percentage. In this case, the calculated result known to be 0,084 . It means that the teacher competencies variable directly affects the student learning outcome variable by $8.4 \%$ while $(100 \%-8,4 \%)$ $91,6 \%$ is influenced by other factors beyond the teacher competencies variable

\section{Discussion}

The purpose of this research was to determine the effect of teacher competencies on student achievement. The results of the research analysis can be summarized as in Figure 1. 


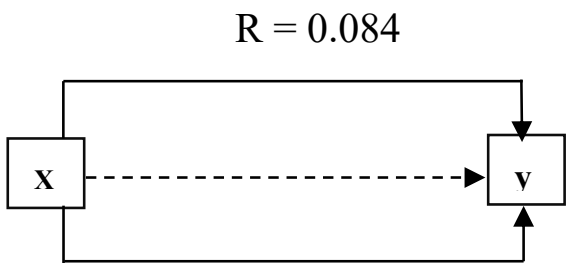

Figure 1. The Effect of Variable $\mathrm{X}$ on Variable $\mathrm{Y}$

The significance of the variables $\mathrm{X}$ and $\mathrm{Y}$ in Figure 1 showed that teacher competencies have a positive and significant effect on student learning outcomes. The conclusions of this research are consistent with the conclusions from previous studies (Ugbe \& Agim, 2009). Ugbe \& Agim (2009) explained that there is a significant influence between teacher competencies and student academic achievement. This may be due to the fact that teacher competencies is a major asset for the student learning quality at school. Teachers who are competent in their work will have qualities that enable them to inspire and develop the capacity of student abilities and will automatically affect the student academic performance. A qualified teacher also has good classroom control, effective communication skills, adequate knowledge on the subject, and can utilize varied teaching strategies to improve student learning outcomes.

The research findings explained that many factors influence student achievement in the classroom. The data analysis results stated that the teacher competencies variable directly affects the student learning outcome variable by $8.4 \%$. It means that $91.6 \%$ of student learning achievement is influenced by factors other than the teacher competencies. Previous research results indicated that the factors other than the teacher competencies are students' motivation (Levpuscek \& Zupancic, 2008), students' perceptions on the school environment (Gietz \& McIntosh, 2014), teachers' attitudes (Levpuscek \& Zupancic, 2008), values and achievement motivation (Suyatno et al., 2019), and class composition (Gottfried, 2012).

The research findings recommend the importance of developing the teacher competencies in schools so that student achievement can be increased. Passos (2009) explained that competencies can be developed through formal teacher training, teacher experience in teaching, and trainings organized by schools as well as trainings that teachers participate independently. In contrast to Passos (2009), Fathivajargah (2003) emphasized the importance of considering the teachers' potential in teacher recruitment. In teacher recruitment, it is necessary to consider high cognitive abilities as well as emotional and practical competencies. In addition to the recruitment matter, teacher competencies development also needs to pay attention to the assessment of teacher performance on a regular basis. Teacher competencies assessment is not only to determine the extent of the mastering of learning material but also encourage teacher to self-development (Wilkerson \& Lang, 2007). Teacher performance assessment can also ultimately: (1) improve teacher performance in performing professional tasks (improvement function); and (2) ensuring teachers to perform better in developing student learning (the accountability function) (OECD, 2009). In addition, teachers need to manage an effective teaching and learning processes so that students know how to learn and utilize their knowledge appropriately in daily lives, and then live in society with happiness. Therefore, teachers need to 
develop competencies in accordance with the education transformation in practice and professional activities effectively (Surasak, 2013).

\section{Conclusion}

Teacher competencies play an important role in improving student learning achievement. The results of the hypotheses indicate that teacher competencies has an influence on student learning outcomes with a dissemination coefficient which shows the direct effect of teacher competencies variable on learning outcomes, which stated in a percentage. In this case, the calculated result is 0,084 . It means that the teacher competency variable directly affect the student learning outcome variable by $8,4 \%$. Teacher competencies have a positive and significant impact on student learning outcomes. This shows that teacher competencies must be improved to maximize student learning outcomes. In developing teacher competencies, competencies aspect must be used to improve teacher professionalism and be taken into consideration when formulating policies and programs for teacher professionalism improvement.

\section{Acknowledgement}

The author would like to thank the Master of Educational Management Study Program that has provided assistance in writing the article, and also Muhammadiyah 1 Bambanglipuro Vocational High School that has given permission to the researchers in exploring research data.

\section{References}

Abe, T. O., \& Adu, E. I. (2014). The effect of teachers' qualifications on students' performance in mathematics. Sky Journal of Educational Research, 2(1), 010-014.

Akiri, A. A. (2013). Effects of Teachers' Effectiveness on Students' Academic Performance in Public Secondary Schools; Delta State - Nigeria. Journal of Educational and Social Research, 3(3), 105. https://doi.org/10.5901/jesr.2014.v4n1p267

Baedowi, A. (2015). Manajemen Sekolah Efektif. Jakarta: PT. Pustaka Alvabet.

Baumert, J., \& Kunter, M. (2006). The COACTIV model of teachersi professional competence. Jerman: Center for Educational Research, Max Planck Institute for Human Development. https://doi.org/10.1007/978-1-4614-5149-5_2

Carreker, S., \& Boulware, R. (2015). The personal competencies through the eyes of the classroom teacher. Center on Innovations in Learning, Temple University, Philadelphia, PA.

Cunningham, J. (2012). Student achievement. In Washington DC, US: National Conference of State Legislatures. 
Darling-Hammond, L. (2000). Teacher quality and student achievement. Education policy analysis archives, 8,1 . https://doi.org/10.14507/epaa.v8n1.2000

Djamarah, S. B. (2011). Psikologi Belajar. Jakarta: PT. Rineka Cipta

Fathivajargah, K. (2003). Standard School (7rd ed.). Tehran: Fakher

Gietz, C., \& McIntosh, K. (2014). Relations between student perceptions of their school environment and academic achievement. Canadian Journal of School Psychology, 29(3), 161-176. https://doi.org/10.1177/0829573514540415

Gottfried, M. A. (2014). Peer effects in urban schools: Assessing the impact of classroom composition on student achievement. Educational Policy, 28(5), 607-647. https://doi.org/10.1177/0895904812467082

Hadis, A., \& Nurhayati, B. (2012). Manajemen Mutu Pendidikan. Bandung: Alfabeta.

Hamalik, O. (2008). Pendidikan Guru Berdasarkan Persetujuan Kompetensi. Jakarta.

Heck, R. H. (2007). Examining the relationship between teacher quality as an organizational property of schools and students' achievement and growth rates. Educational administration quarterly, 43(4), 399-432. https://doi.org/10.1177/0013161x07306452

Hospesová \& Tichá, M. (2000). Developing mathematics teacherís competence. Research report supported by the Socrates Comenius project 87636-CP-1-2000-1-CZComenius-C31 and GACR 406/02/0829 and 406/05/2444.

Inayah, R., Martono, T., \& Sawiji, H. (2013). Pengaruh Kompetensi Guru, Motivasi Belajar Siswa, dan Fasilitas Belajar Terhadap Prestasi Belajar Mata Pelajaran Ekonomi Pada Siswa Kelas XI IPS SMA Negeri 1 Lasem, Jawa Tengah Tahun Pelajaran 2011/2012. Jurnal Pendidikan Insan Mandiri, 1(1), 1-2.

Jennings, P. A., \& Greenberg, M. T. (2009). The prosocial classroom: Teacher social and emotional competence in relation to student and classroom outcomes. Review of educational research, 79(1), 491-525. https://doi.org/10.3102/0034654308325693

Joy, Hamilton, T., \& Ekeke. (2013). Conceptual Framework of Teachers' Competence In Relation To Students' Academic Achievement. International Journal of Networks and Systems, 2(3), 6.

Kunter, M., Klusmann, U., Baumert, J., Richter, D., Voss, T., \& Hachfeld, A. (2013). Professional competence of teachers: Effects on instructional quality and student development. Journal of Educational Psychology, 105(3), 805. https://doi.org/10.1037/a0032583

Lee, J., Liu, X., Amo, L. C., \& Wang, W. L. (2013). Multilevel Linkages between State Standards, Teacher Standards, and Student Achievement: Testing External versus Internal Standards-Based Education Models. https://doi.org/10.1177/0895904813475708

Levpuscek, M. P., \& Zupancic, M. (2008). Math Achievement in Early. Journal of Early 
Adolescence, $X X(\mathrm{X}), 1-30$. https://doi.org/10.1177/0272431608324189

Mulyasa, E. (2007). Standar Kompetensi dan Sertifikasi Guru. Bandung: PT. Remaja.

Musau, L. M., \& Abere, M. J. (2015). Teacher Qualification and Students' Academic Performance in Science Mathematics and Technology Subjects in Kenya. International Journal of Education Administration and Policy Studies, 7(3), 83-89 https://doi.org/10.5897/ijeaps2014.0386

Muzenda, A. (2013). Lecturers' Competences and Students' Academic Performance. International Journal of Humanities and Social Science Invention, 3(1), 6.

Nemeth, J., \& Long, J. G. (2012). Assessing Learning Outcomes in U.S. Planning Studio Courses. Journal of Planning Education and Research, 32(4), 476-490. https://doi.org/10.1177/0739456x12453740

Nessipbayeva, O. (2012). The Competencies of the Modern Teacher. Bulgarian Comparative Education Society.

Novauli, F. (2012). Pengaruh Kompetensi Guru Terhadap Peningkatan Prestasi Belajar Pada SMP Negeri di Kota Banda Aceh. Jurnal Pencerahan, 6(1), 18.

OECD. (2009). Teacher evaluation: a conceptual framework and examples of country practices. Paper was prepared for presentation at the OECD-Mexico Workshop towards a Teacher Evaluation Framework in Mexico: International Practices, Criteria and Mechanisms, Mexico City. https://doi.org/10.1787/223283631428

Ottmar, E. R., Rimm-Kaufman, S. E., Larsen, R. A., \& Berry, R. Q. (2015). Mathematical knowledge for teaching, standards-based mathematics teaching practices, and student achievement in the context of the responsive classroom approach. American Educational Research Journal, 52(4), 787-821. https://doi.org/10.3102/0002831215579484

Parker-Stanford, C. (2014). Good English Teachers Improve Math Scores for Students. Stanford University.

Passos, A. F. (2009). A Comparative Analysis of Teacher Competence and Its Effect on Pupil Performance in Upper Primary Schools in Mozambique and other SACMEQ Countries. University of Pretoria. Unpublished PHD Thesis, 38-45.

Prasertcharoensuk, T., Somprach, K. L., \& Ngang, T. K. (2015). Influence of teacher competency factors and students' life skills on learning achievement. Procedia-Social and Behavioral Sciences, 186, 566-572. https://doi.org/10.1016/j.sbspro.2015.04.021

Redding, S. (2014). Personal Competencies in Personalized Learning. Center on Innovations in Learning, Temple University.

Surasak, P. (2013). Teacher competency development in the 21st Century. Paper presented in Seminar and Educational Staff, under the Office of Prae Primary Educational Service Area 1-2. Teacher development program by developing the mentor system. Prae: Nakon Prae Tower Hotel. 
Suyatno, S., Wantini, W., Baidi, B., \& Amurdawati, G. (2019). The Influence of Values and Achievement Motivation on Teacher Professionalism at Muhammadiyah 2 High School Yogyakarta, Indonesia. Pedagogika, 133(1). https://doi.org/10.15823/p.2019.133.6

Taghipourzahir, A. (2010). Principles of education (7th ed). Tehran: Agah

Trinder, J. C. (2008). Competency Standards - A Measure of the Quality of a Workforce. The International Archives of the Photogrammetry. Remote Sensing and Spatial Information Sciences, 37(B6a), 165-168.

Ugbe, A. U., \& Agim, J. I. (2009). Influence of teachers' competence on students academic performance in senior secondary school chemistry. Global Journal of Educational Research, 8(1-2). https://doi.org/10.4314/gjedr.v8i1-2.53770

Wayne, A. M., \& Youngs, P. (2003). Teacher characteristics and student achievement gains: A review. Review of Educational Research, 73(1), 89-122. https://doi.org/10.3102/00346543073001089

Wilkerson, J. R., \& Lang, W. S. (2007). Assessing teacher competency: five standardsbased steps to valid measurement using the CAATS model. United States: Corwin Press. https://doi.org/10.1080/08957340802558417

Zuzovsky, R. (2003). Teachers' Qualifications and their Impact on Student Achievement: Findings from TIMSS 2003 data for Israel. Center for Science and Technology Education. Tel Aviv University, Tel Aviv, Israel, 37-62.

\section{Copyright Disclaimer}

Copyright for this article is retained by the author(s), with first publication rights granted to the journal.

This is an open-access article distributed under the terms and conditions of the Creative Commons Attribution license (http://creativecommons.org/licenses/by/3.0/). 